\author{
Anna BUSLOWSKA, PhD \\ Faculty of Economics and Finance, University of Bialystok \\ e-mail: a.buslowska@uwb.edu.pl \\ ORCID: 0000-0003-2581-3801
}

DOI: $10.15290 /$ oes.2020.01.99.10

\title{
INTEGRATED TERRITORIAL INVESTMENTS AND THE IMPROVEMENT OF TRANSPORT MOBILITY AND ACCESSIBILITY OF URBAN FUNCTIONAL AREAS - THE EXAMPLE OF THE BIALYSTOK FUNCTIONAL AREA ${ }^{1}$
}

\begin{abstract}
Summary
Purpose - The aim of the paper is to identify the activities implemented as part of the Integrated Territorial Investments (ITI) in order to improve transport accessibility and mobility using the example of the investments undertaken in the Bialystok Functional Area (BFA). The formulated hypothesis implies that in the Bialystok Functional Area support is available for various projects financed from ITI in order to improve transport mobility and accessibility.

Research method - The analysis was based both on a literature review of the subject and using the Author's own research conducted in October 2019 on the Bialystok Functional Area Association (BFAA), including the data from the IT system - SL 2014. The analysis was based on the case studies of the projects implemented within ITI funds within the frame of improving the mobility and transport accessibility in the BFA. The analysis was supplemented with statistical research and a survey which was conducted among the employees of ten BFA municipalities responsible for the implementation of transport investments.

Results - The analysis demonstrated that the projects aimed at improving the mobility and transport accessibility are undertaken by the majority of BFA municipalities. These activities are varied and adjusted to the needs of specific local government units, with a high share of funding for this type of undertakings. The undertaken investments focus, specifically on the development of the bicycle paths network and the road infrastructure. The implemented projects will not solve all the transport problems of the BFA, however they constitute an important element that ensures mainly the increase of the availability of Park \& Ride and Bike \& Ride infrastructure and municipal public transport services.

Originality / value - The integrated territorial investment is a new instrument of the European Union cohesion policy. It is specifically dedicated for the functional urban areas. Hence it is a new research topic, the study of which will be important to determine the pros and cons of the new ITI instrument and its assessment in the development of cities and their functional areas.
\end{abstract}

Keywords: integrated territorial investments, functional area, mobility

JEL Classification: O18, O21

${ }^{1}$ Article received on 06 September 2019, accepted on 2 December 2019. 


\section{Introduction}

One of the basic elements of the development of modern cities is transport. The necessity to move is the effect of the social and production sphere of human activity and determines the demand for transport services. The demand for transport is permanent and unlimited. The development of transport (of passengers and goods) results in the increased mobility of users of the entire transport system.

The Integrated Territorial Investments (ITI) is a new instrument of the cohesion policy in the present financial perspective of the European Union (EU). It enables the realization of territorial strategies in an integrated way, especially within the sustainable development of urban functional areas. As the instrument it serves the realization of development goals in a holistic manner. It is useful for solving the problems of an economic, environmental, climate, demographic and social type which have been diagnosed functional areas. Among them, transport mobility and accessibility stand out as the most important spheres. Bearing in mind the specific character of the functional area, as an extensive area composed of varied territorial units, the postulate is particularly essential.

This paper aims to identify those activities realized within the ITI that serve the improvement of accessibility and mobility in the example of the investments made in the Bialystok Functional Area (BFA). The adopted hypothesis implies that in the Bialystok Functional Area support is provided for various tasks improving transport mobility and accessibility financed from the ITI instrument. The considerations were based both on the subject literature and using the Author's own research conducted in October 2019 in the Bialystok Functional Area Association. The case study technique was utilized - these projects were realized in the ITI and contributed to the improvement of the transport mobility in Bialystok Functional Area. The analysis was supplemented with statistical data and the results of the survey undertaken among the employees responsible for the realization of the investments connected with transport in a particular BFA self-government.

\section{The Integrated Territorial Investments as an instrument of supporting urban functional areas}

The essence of the ITI instrument is to ensure the mechanism of integrated answers to the diverse needs formulated within the development strategy of the functional areas. The basic conditions connected with mobilizing ITI resources include, among others [Ustawa, 2014, p. 34]:

- establishing the ITI association or signing either a contract or agreement with the local territorial units located in the ITI realization place,

- elaborating the strategy of development of a particular area by the entities forming the ITI, 
- signing a contract or agreement concerning the realization of ITI between the ITI association and a proper institution responsible for the regional operational program.

The ITI instrument is realized in functional areas. Their definitions may be found in the national planning and strategic documents. It appears there as the urban functional area (UFA), i.e. the settlement system composed of separate administrative units maintaining the spatial continuity and made up of a city and its functionally connected urbanized zone [Koncepija przestrzennego zagospodarowania ..., 2012, pp. 187-194]. It is also specified as the area of compact spatial arrangement with functional relations and mutual development goals [Ustawa, 2003, p. 4]. In general, during the analysis of the subject literature one may identify four basic types of UFA: districts (including metropolies) and the regional, sub-regional and local type [Koncepcja przestrzennego zagospodarowania..., 2012, pp. 187-194; Ustawa, 2003, p. 55]. In order to realize the ITI, the delimitation of UFA district center was elaborated on the basis of P. Śleszyński's methodology based on 3 groups of indicators (functional, socio-economic and morphological) [Kryteria delimitacji..., 2013, p. 7]. In relation to other functional areas of regional/sub-regional importance they were indicated based on individual analyses. For the purpose of ITI realization in the area of district towns and functionally interrelated areas the UFA had to comprise: the district city, all of the cities from the functional area core and other municipalities of the functional area - in total, at least one half of the municipalities designated on the basis of the aforementioned document. In the area of district cities and their functionally interrelated areas the ITI is obligatorily financed using the funds from the regional operational program which is possible thanks to isolating activities or sub-activities within at least priority axes financed from two structural funds. At the level of all the regional operational programs (ROP) the allocation necessary for this goal in relation to the total allocation of particular funds accruing to Poland amounts to at least $5.2 \%$ of the allocation of ERDF and $2.4 \%$ of the allocation of ESF. The realization of ITI in other functional areas in the district depended on the decision of self-governments of particular regions [Programowanie perspektyny..., 2017, pp. 219 -228]. The strategies of the development of functional areas constituted the basis for the realization of various undertakings and the distribution of ITI funds. In this way the policy related to urban functional areas constitutes an essential factor of support by means of better definition of their development potentials and is a complex method of solving the problems occurring there [Krajowa Polityka Miejska..., 2015, p. 11]. The priorities for the development of functional areas within ITI include mainly: increasing the competitiveness and attractiveness of labor markets, ensuring effective transport between a city and its functional area, realizing the plans of a low-emission economy and improving the state of the natural environment as well as reinforcing research, innovations and the city network [Programowanie perspektymy..., 2017, p. 220].

In the regional development theory, the development based on UFA and co-financing from the ITI fits into the group of theories that emphasize the role of a certain area in creating the development mechanisms - the so-called development 
'grassroots' theories. A certain area is indicated as the creator of its own development not only in the context of cooperation, but also as regards the dependence from the close surrounding, while the subjectivity and knowledge of the region and local settlement units are considered as the main starting point for undertaking any development activities [Gałązka, 2017, pp. 36-37].

\section{Transport accessibility and mobility shaping}

Transport has several definitions in the subject literature reviewed. It is understood as the technical, organizational and economic unbundling from other activities aiming at moving people, loads and energy. Apart from movement, the concept of transport comprises additional activities such as handling, preparation of the means of transport and the activities connected with organizing the change of place. Transport is related to the usage of certain means of transport, infrastructure and business entities providing transport services, which decides upon its classification diversity [Mendyk, 2009, p. 11; Rydzkowski, Wojewódzka-Król, 2010, pp. 1-3; Ekonomiczne i organizacyjne..., 2013, p. 9, Wojewódzka-Król, Załoga, 2016, pp. 5-7]. The provision of transport services is based on using infrastructure and the means of transport. Their existence determines the functioning of economy because these are the technical elements that enable movement in various branches of transport. In this context the problems of shaping such transport system that meets the needs of the participants of the transport process and guarantees accessibility and mobility is gaining a special dimension.

In the subject literature, transport accessibility is described and measured in several ways and it is difficult to find only one generally accepted definition. It is pointed out that this is a certain degree of transport management of a certain area [Kwarciński, 2012, p. 170]. Additionally, emphasis is laid upon certain property of the place, which is related to a certain form of moving from one place to another [Ingram, 1970, pp. 101-105]. Additionally, it is associated with a certain product of the transport system that determines the benefit of the location of a certain area (e.g. a region, city) in relation to others [Spiekermann, Neubauer, 2002, p. 7].

Meanwhile, mobility is defined as the manifestation of spatial mobility (localization and communication behaviors) being the subject of interest of the transport policy and urban planning in the social, economic and environmental aspect. The basis of mobility is the necessity of the transfer of persons and loads in the form of communication, using various means of transport [Kalisiak-Mędelska, 2017, p. 39]. According to J. Szoltysek [2009, p.70] the maintenance of mobility is the main element of man's independence, whereas the easy access to other people and the possibility of achieving various objectives determines a good living standard and hence requires a proper means of transport. However, mobility means not only the journeys by various vehicles. Mobility relates to walking or using vehicles powered by the muscular energy of people or animals. Mobility may be also treated in either non-material or virtual dimension [Szołtysek, 2016, pp. 57-58]. Moreover, it is 
emphasized that mobility specifies the difficulty with the access to destinations which, in turn, defines the degree of participating in the „contemporary life” [Hernandez, 2017, pp. 119-125].

The aspect of the analysis of the aforementioned phenomena is complex. Among the subject analysts there is considerable diversity as regards the classification of the analysis methods of transport accessibility [comp. Rosik, Pomianowski et al., 2017, p. 28] In the subject literature one of the basic measures describing accessibility as the equipment in transport infrastructure [Wojewódzka-Król, Rolbiecki, 2018, p. 30; Kwarciński, 2012, p. 170, Rosik, Pomianowski et al., 2017, p. 28]. However, there may be other isolated indicators, e.g. [Rosik, Pomianowski et al., 2017, pp. 28-29]:

- connected with the distance - the accessibility measured in terms of the physical, time or economic distance from reaching the goal,

- cumulative accessibility - related to the estimation of the collection of journey destinations available in a certain time period at certain cost or the effort of travelling,

- potential accessibility - i.e. measured in terms of the potential possibility of the interactions between the journey source and the destination,

- personalized accessibility - regards measurements in the so-called time and space prism, using a collection of alternative travelling paths from the journey source to its destination while taking into consideration the behaviors and preferences of the users of the transport system.

Furthermore, it needs emphasizing that the changes of accessibility regard simultaneously many branches of transport. Therefore, it is crucial to create synthetic indicators in the multimodal perspective, e.g. on the basis of potential accessibility there was formulated the indicator of input-output accessibility of WMDT used for the first time in Poland in 2008 to calculate the changes of accessibility as the result of realizing the investment in transport infrastructure at the provincial level [Komornicki, Rosik et al., 2018, pp. 8-10].

In a certain paper, transport mobility and accessibility will be analyzed in the perspective of the development of the equipment in transport infrastructure and public means of transport of the BFA area using the ITI instrument. In accordance with the Partnership Agreement [Programowanie perspektyny..., 2017, p. 220] the support from ITI includes the support within most (CT). Among the main challenges there are listed: the development of sustainable and efficient transport enabling connection of the city with its functional area (CT4, CT7). In Poland in ITI associations within CT7 (the promotion of sustainable transport and the removal of capacity deficiencies as regards the functioning of the most important network infrastructure) there are realized 31 projects worth approx. $730 \mathrm{mln}$ PLN, whereas in CT 4 (the support for the shift towards low emission economy in all the sectors) - there are 691 projects worth approx. $6.7 \mathrm{bln}$ PLN. At the present stage of ITI implementation most projects $(32 \%)$ having at the same time the largest total value $(53 \%)$, regards CT4. However, one should bear in mind that the projects realized here (apart from transport public and bike infrastructure) regard also energy effectiveness and air quality, which leads to a certain difficulty with estimating the 
effects regarding transport on a national scale [Ewaluacja systemu realizacji instrumentu..., 2018, p. 89].

\section{The improvement of transport mobility and accessibility using the ITI funds in the Białystok Functional Area}

The Białystok Functional Area comprises 10 municipalities: Białystok, Choroszcz,

Czarna Białostocka, Dobrzyniewo Duże, Juchnowiec Kościelny, Lapy, Supraśl, Turośń Kościelna, Wasilków and Zabłudów. It occupies an area of approx. 1,728 km² (i.e. approx. $9 \%$ of Podlaskie district area). It is inhabited by approx. 411.5 thousand people. It constitutes slightly more than $34 \%$ of the inhabitants of Podlaskie district, whereas approx. $72 \%$ of the BFA population live in Białystok [Strategia Zintegrowanych..., 2019, pp. 12-18]. The development of a certain area concentrates on the construction of a strong socio-economic center that is open to cooperation and guarantees high living standard. The priorities of development concentrate on seven objectives: investment attractiveness; work competences; accessibility for culture; active social integration; low emission economy and environmental protection; communication accessibility and the integration of strategic management of BFA development [Strategia Zintegrowanych..., 2019, p. 166].

In 2016, there were more than $590 \mathrm{~km}$ of municipal roads in the BFA, including approx. $465 \mathrm{~km}$ of a higher quality road surface. The system of bicycle paths comprised the network having the length of approx.. $149 \mathrm{~km}$ (one third of the district network), including approx. $112 \mathrm{~km}$ in Białystok. An important part of the urban infrastructure are also bus lanes located in the main communication routes in Białystok having the total length of approx. $12,8 \mathrm{~km}$. The Białystok Public Transport Company (Białostocka Komunikacja Miejska - BKM) provides services for some municipalities forming the BFA, i.e.: Choroszcz, Zabłudów, Juchnowiec Kościelny, Dobrzyniewo Duże, Wasilków and Supraśl. The length of bus lanes in the BFA amounted to $526 \mathrm{~km}$ (approx. 45\% of the network in the district) and included tabor composed of 216 buses [Bialostocki Obszar Funkcjonalny..., 2018, p. 117].

Within the ITI funds there are 5 projects concerning the improvement of transport mobility and accessibility: 2 within CT4, i.e.: Projekt partnerski: Rozwój niskoemisyjnego transportu zbiorowego $i$ rowerowego w BOF - Partnership Project; The development of low emission public and bicykle transport in BFA (realized by 9 municipalities of BFA, apart from Turośń Kościelna) and Utworzenie centrum przesiadkowego w Lapach (dworzec $i$ teren PKS) - The establishment of the transfer node in Lapy (realized by Lapy municipality) as well as 3 projects within CT7: Poprawa dostępności komunikacyjnej terenów inwestycyjnych $w$ Lapach (The improvement of communication accessibility of the investment areas in Lapy, Projekt zintegrowany: Poprawa dostęnośsi do terenów inwestycyjnych pray ul. Kodeksu Supraskiego (Integrated project: The improvement of accessibility to the investment areas near Kodeksu Supraskiego street), Projekt zintegrowany: Uzbrojenie terenów inwestycyjnych w Zabludowie (Integrated project: The structural works of the investment areas in Zabludów). In general, the 
financing within the ITI for the aforementioned projects constitutes approx. 31\% of the total allocation for the BFA area.

The agreement on the financing of the first among the aforementioned projects was signed in 2017, whereas the realization will last till 2020. As the main objective the applicants adopted the improvement of the living standard of the inhabitants by means of the development of environmentally friendly public transport systems and bicycle transport in BFA. The project includes the following works: the purchase of low emission fleet for the needs of urban transport, the provision of roads and streets with the infrastructure for urban transport (bus bays and termini) and passengers (bus stops and shelters), the construction of bicycle paths and pedestrian/bicycle routes with the necessary infrastructure as well as the construction and reconstruction of municipal and provincial roads with the aim of improving the infrastructure of public transport and create new transportation links (increasing the territorial coverage of BKM. The detailed list of works carried out by specific project partners is presented in table 1. The total budget on the realization of the aforementioned activities amounts to $159.3 \mathrm{mln}$ PLN, while the community funds amounted to $90.3 \mathrm{mln}$ PLN. The general effects of realizing the aforementioned set of tasks include: 140 Bike\&Ride infrastructure positions, 1 new ITS system, 12 new buses of the urban transport system with the total capacity of 720 persons, $48.27 \mathrm{~km}$ of new cycle paths, $21.23 \mathrm{~km}$ of either new or modernized public transport lines. Thanks to the realization of these indicators by $4 \%$ there will be more public transport lines in the BFA and the size of the public transport fleet will increase by $5 \%$. Considerable increase regards mainly the length of bicycle paths which will increase by $32 \%$ in the entire BFA. The length of the road infrastructure is predicted to increase by $3.5 \%$ in comparison with 2016 .

TABLE 1

\section{The list of tasks realized within the project Partnership project: The dev elopment of low emission public and bicycle transport in BFA}

\begin{tabular}{|l|l|}
\hline $\begin{array}{l}\text { The name of the } \\
\text { municipality }\end{array}$ & \multicolumn{1}{c|}{ The type of realized tasks and the effects } \\
\hline $\begin{array}{l}\text { The city of } \\
\text { Białystok (the } \\
\text { leader) }\end{array}$ & $\begin{array}{l}\text { The construction of bicycle paths and pedestrian/bicycle routes } \\
\text { (approx. 14.7 km), the purchase of bicycle racks (51), the purchase of } \\
\text { low emission buses (12), the assembly of the ITS system }\end{array}$ \\
\hline Choroszcz & $\begin{array}{l}\text { The construction of bicycle paths and pedestrian/bicycle routes } \\
\text { (approx. 11 km), the construction and reconstruction of municipal and } \\
\text { provincial roads (7.6 km), the construction of bicycle parking } \\
\text { positions in „Bike\&Ride” places (23) }\end{array}$ \\
\hline $\begin{array}{l}\text { Czarna } \\
\text { Białostocka }\end{array}$ & $\begin{array}{l}\text { The construction of bicycle paths and pedestrian/bicycle routes } \\
\text { (approx. } 8,5 \mathrm{~km}), \text { the construction of bicycle parking positions in } \\
\text { „Bike\&Ride” places (6) }\end{array}$ \\
\hline $\begin{array}{l}\text { Dobrzyniewo } \\
\text { Duże }\end{array}$ & $\begin{array}{l}\text { The reconstruction of provincial roads (4.2 km) and the construction } \\
\text { of bicycle paths }(1.2 \mathrm{~km}), \text { the construction of bicycle parking positions } \\
\text { in „Bike\&Ride” places (10) }\end{array}$ \\
\hline
\end{tabular}


Integrated territorial investments and the improvement of transport ...

\begin{tabular}{|l|l|}
\hline $\begin{array}{c}\text { The name of the } \\
\text { municipality }\end{array}$ & \multicolumn{1}{c|}{ The type of realized tasks and the effects } \\
\hline $\begin{array}{l}\text { Juchnowiec } \\
\text { Kościelny }\end{array}$ & $\begin{array}{l}\text { The construction of bicycle paths and pedestrian/bicycle routes } \\
\text { (approx.12 } \mathrm{km} \text { ), the construction of roads (3.5 km) including a bus } \\
\text { terminus, the construction of bus bays (15), the construction } \\
\text { of bicycle parking positions in „Bike\&Ride” places (19) }\end{array}$ \\
\hline Lapy & $\begin{array}{l}\text { The construction of bicycle paths (approx. 2.1 km), the construction } \\
\text { of bicycle parking positions in „Bike\&Ride” places (4) }\end{array}$ \\
\hline Supraśl & $\begin{array}{l}\text { The construction of municipal and provincial roads (approx. } 2 \mathrm{~km}), \\
\text { the construction of bicycle parking positions in „Bike\&Ride” places }(6)\end{array}$ \\
\hline Wasilków & $\begin{array}{l}\text { The construction of bicycle paths (approx. 4.2 km), the construction } \\
\text { and reconstruction of a municipal road (2 km), the construction } \\
\text { of bicycle parking positions in „Bike\&Ride” places (15) }\end{array}$ \\
\hline Zabłudów & $\begin{array}{l}\text { The construction of pedestrian/bicycle routes (0.83 km), the } \\
\text { construction and reconstruction of a municipal road (1.8 km), the } \\
\text { construction of bicycle parking positions in „Bike\&Ride” places (6) }\end{array}$ \\
\hline
\end{tabular}

Source: own elaboration of the basis of: [SBOF, 2019].

The supplementation of the aforementioned activities is the investment referring to the creation of the intermodal transfer node in Lapy, the realization agreement of which was signed also in 2017 , but the works are going to be continued until the end of 2019. The activities in the project will comprise the management of the railway and bus stations (PKP and PKS), which will contribute to the integration and creation of conditions for the functioning of the complementary types of transport (by train, car and bicycle). A detailed list of works includes, among others, the hard surfacing of the maneuvering yards for buses, the construction of access roads and parking lots for passenger cars, the construction of sidewalks, the lightning of the area, the change of colliding installations, the placement of the installations under the construction site, the construction of bus shelters and bicycle racks, the creation of green areas, including a playground. The planned project products are related to the construction of the Park\&Ride infrastructure with the total number of places amounting to 78 and Bike\&Ride infrastructure (48 parking places). Additionally, the investor anticipates that annually the Park\&Ride infrastructure will be used by 10,625 vehicles. It is important because so far there has not been any infrastructure of this type in the BFA region [GUS, BDL]. The budget of the aforementioned project amounts to approx. $7.5 \mathrm{mln}$ PLN, including the funds from the EU worth $5.8 \mathrm{mln}$ PLN. The main aim of the project is to increase the mobility of BFA inhabitants and the development of low emission public and bicycle transport in the total service offered for the inhabitants of a certain area [SBOF, 2019].

A separate group of projects within ITI constitute the already completed investments finalized in 2018 in three municipalities (Lapy, Supraśl and Zabłudów) - they regarded the improvement of transport accessibility of the investment areas in the above-mentioned territorial units. The activities were chiefly connected with the construction and reconstruction of access roads to the investment areas and at the 
same time enabled the supplementation and improvement of the public road network in the BFA. Within the projects realized in the aforementioned institutions it was possible to construct the total of $0.93 \mathrm{~km}$ of new municipal roads (it increased the total length of municipal roads by $0.16 \%$ in comparison with 2016), whereas further $3.19 \mathrm{~km}$ were reconstructed (increasing thus by further $0.5 \%$ the general network of municipal roads in the BFA in comparison with 2016). The total expenditures in these projects amounted to approx. $14.5 \mathrm{mln}$ PLN, whereas the EU funds - approx. $6.5 \mathrm{mln}$ PLN [SBOF, 2019].

The above-mentioned activities show that the improvement of mobility and accessibility constitute an important challenge for the development of functional areas. The evidence of this are also the results of the survey conducted in $10 \mathrm{BFA}$ municipalities ${ }^{2}$. When asked about the impact of the project/s realized within ITI for the improvement of transport mobility and accessibility one half of the surveyed municipalities evaluated it as average. In 4 municipalities this impact was evaluated as very good, in the self-governments located near Bialystok, where (thanks to realizing the partnership project there will be activated new public transport lines. Simultaneously it was demonstrated that the share of ITI funds in financing these undertakings during the period 2014-2020 was considerable only for 2 self-governments (financing above 51\%), in other cases the percentage of financing oscillated from 25 to 50 . At the same time the respondents stated that the level of mobility and transport accessibility of their municipality (despite the investments being made) is still unsatisfactory (4 such situations), in two cases it was assessed as low or very low, whereas in the other cases - as good. As regards the necessity of providing further support of mobility and transport accessibility the respondents mentioned the following main areas: the investments in road infrastructure (all the municipalities), the investments in bicycle infrastructure (6 municipalities) as well as Park \& Ride and Bike \&Ride infrastructures (2 municipalities), as well as in the development of the urban public transport (2 municipalities).

\section{Conclusions}

The paper concerns the analysis of projects and their effects realized from the ITI instrument in the Białystok Functional Area contributing to the improvement of transport accessibility and mobility. The paper aimed at identifying the activities realized within ITI and serving the improvement of accessibility and mobility on the example of the investments made in BFA. Transport. The following final conclusions may be drawn from the conducted analysis:

- the funds from the ITI instrument serve the improvement of transport accessibility and mobility in the BFA, but the impact is diverse;

\footnotetext{
2 Survey (a questionnaire conducted by phone calls) was conducted among 10 employees of municipality offices in BFA (managers, the deputies of the voit/mayor) responsible for the implementation of infrastructural investments in a certain municipality.
} 
- the investments concerning the development of the public transport infrastructure constitute the main area of investments from ITI and the future basic need to improve accessibility,

- considerable improvement of mobility occurred in the sphere of bicycle transport because all the BFA municipalities made investments necessary to construct bicycle paths and/or parking places within Bike\&Ride,

- the realized projects will contribute to the formation of first ever Park\&Ride infrastructure in BFA,

- the expansion of the quality of the services provided by public transport company will be improved due to the purchase of new buses and investments in infrastructure,

- measurable effects will include also the benefits for the environment which result not only from the planned usage of low emission buses, but also from the reconstruction of the bike infrastructure.

To sum up, it should be emphasized that the projects realized presently do not solve all the problems related to accessibility and mobility in the BFA. However, they constitute solely one step which guarantees the increase of the possibilities of selecting the ways of moving in a certain functional area by means of the development of infrastructure and means of transport necessary to reach this objective. However, further steps need to be taken especially in order to increase the multimodal character of transport in the BFA and ensure further improvement of transport connections between Bialystok and the neighboring municipalities.

\section{References}

Biatostocki Obszar Funkcjonalny w latach 2014-2016, 2018, Urząd Statystyczny w Białymstoku, Białystok.

Ekonomiczne i organizacyjne aspekty transportu, 2013, Urbanyi-Popiołek I. (red.), Wydawnictwo Uczelniane Wyższej Szkoły Gospodarki w Bydgoszczy, Bydgoszcz.

Ewaluacja systemu realizacii instrumentu ZIT w perspektymie finansowej UE na lata 20142020. Raport koncony, 2018, Wolański M.. (red.), EGO - Evaluation for Government Organizations S.C., Warszawa.

Gałązka A., 2017, Teoretyczne podstany rozwoju regionalnego - wybrane teorie, cazynniki $i$ bariery rozwoju regionalnego, „Studia BAS”, nr 1(49), s. 9-61.

GUS, https://bdl.stat.gov.pl/BDL/start [date of entry: 01.10.2019].

Hernandez D., 2017, Uneven mobilities, uneven opportunities: Social distribution of public transport accessibility to jobs and education in Montevideo, ,Journal of Transport Geography", no. 67(C), pp. 119-125, DOI: 10.1016/j.jtrangeo.2017.08.017.

Ingram D.R., 1970, The concept of accessibility: a search for an operational form, "Regional Studies", no. 5, pp. 101-107, DOI: 10.1080/09595237100185131.

Kalisiak-Mędelska M., 2017, Transport $i$ mobilność miejska w śnietle krajowej polityki miejskiej 2023 - ujecie logistyczne, „Prace naukowe Uniwersytetu Ekonomicznego we Wrocławiu", nr 467, s. 33-46, DOI: 10.15611/pn.2017.467.03. 
Komornicki T., Rosik P., Stępniak M., Śleszyński P., Goliszek S., Pomianowski W., Kowalczyk K., 2018, Ewaluacja i monitoring zmian dostepności transportowej w Polsce z. mykoorzystaniem wskaźnike WMDT, Ministerstwo Inwestycji i Rozwoju, Warszawa. Koncepcja przestrzennego zagospodarowania kraju 2030, 2012, Monitor Polski, poz. 252. Krajowa Polityka Miejska 2023, 2015, Ministerstwo Rozwoju, Warszawa.

Kryteria delimitacji obszarón funkcjonalnych ośrodkón wojewódžkich, 2013, Ministerstwo Rozwoju Regionalnego, Warszawa.

Kwarciński T., 2012, Dostepność transportowa jako paradygmat ksz̨tattujacy wielkość przewozów w publicznym transporcie pasażerskim, „Logistyka”, nr 2, s. 169-173.

Mendyk E., 2009, Ekonomika transportu, Wyższa Szkoła Logistyki, Poznań.

Programowanie perspektyny finansowej 2014-2020 - Umowa Partnerstwa, 2017, Ministerstwo Infrastruktury i Rozwoju, Warszawa.

Rosik P., Pomianowski W., Goliszek, Stępniak M., Kowalczyk K., Guzik R., Kołoś A., Komornicki T., 2017, Multimodalna dosteppność transportem publicznym gmin w Polsce (Multimodacc), „Prace Geograficzne”, nr 258.

Rydzkowski W., Wojewódzka-Król K., 2010, Transport, PWN, Warszawa.

SBOF, 2019, Dokumenty wewnętrzne SBOF. System SL 2014 [date of entry: 31.10. 2019].

Spiekermann K., Neubauer J., 2002, European Accessibility and Peripherality: Concepts, Models and Indicators, Nordregio, Stockholm.

Strategia Zintegrowanych Inwestycji Terytorialnych Biatostockiego Obszaru Funkcjonalnego na lata 2014-2020 (wersja 5), 2019, Białostocki Obszar Funkcjonalny, Białystok.

Szołtysek J., 2009, Podstany logistyki miejskiej, Wydawnictwo Akademii Ekonomicznej w Katowicach, Katowice.

Szołtysek J., 2016, Logistyka miasta, PWE, Warszawa.

Ustawa z dnia 11 lipca 2014 r. o zasadach realizacji programów w zakresie polityki spójności finansowanych w perspektywie finansowej 2014-2020, Dz. U. z 2017 r. poz. 1460,1475 z późn. zm.

Ustawa z dnia 27 marca 2003 r. o planowaniu i zagospodarowaniu przestrzennym, Dz.U. 2003 nr 80 poz. 717 z późń. zm.

Wojewódzka-Król K., Załoga E., 2016, Transport-nowe wyzwania, PWN, Warszawa.

Wojewódzka-Król K., Rolbiecki R., 2018, Infrastruktura transportu: Europa, Polska teoria i praktyka, PWN, Warszawa. 